\title{
METABOLISM OF INORGANIC CATIONS BY QUAIL (COTURNIX COTURNIX) DRINKING SOLUTIONS OF $\mathrm{CaCl}_{2}$ AND $\mathrm{MgCl}_{2}$
}

\author{
ERNEST J. WILLOUGHBY*
}

Department of Zoology, The University of Michigan, Ann Arbor, Michigan 48104

(Received 13 fuly 1970)

\begin{abstract}
In experiments to indicate the abilities of birds to tolerate and excrete $\mathrm{Mg}$ and $\mathrm{Ca}$ in drinking water, twenty-eight male quail received solutions of $\mathrm{CaCl}_{2}$ or $\mathrm{MgCl}_{2}$ perenterally for several days or in single doses. The concentrations of $\mathrm{Ca}, \mathrm{Mg}, \mathrm{Na}$ and $\mathrm{K}$ were subsequently measured in excretory fluids voided spontaneously or collected by intubating cloaca and rectum, and in plasma.

2. The physiological mechanisms of quail which deal with divalent cations are affected similarly by both $\mathrm{Ca}$ and $\mathrm{Mg}$, without distinguishing sharply between the two.

3. Calcium appears to be less readily absorbed in the gut than $\mathrm{Mg}$.

4. Excretion of $\mathrm{Na}$ is increased by intake of $\mathrm{CaCl}_{2}$ or $\mathrm{MgCl}_{2}$.

5. Water appears to be absorbed from ureteral urine in cloaca or rectum.

6. The effects of $\mathrm{CaCl}_{2}$ and $\mathrm{MgCl}_{2}$ on salt metabolism of the quail are complex.
\end{abstract}

\section{INTRODUCTION}

DURING the past two decades physiologists have investigated the abilities of various birds to drink hyperosmotic saline solutions and to obtain physiologically useful water from them. These studies have contributed to an understanding of the adaptivc spccializations of birds that live in a varicty of habitats, including marine situations, salt marshes, and deserts, where the salinity or scarcity of water make it difficult to maintain homeostasis (for reviews see Bartholomew \& Cade, 1963: Cade, 1964; Dawson \& Bartholomew, 1968). These studies have dealt only with metabolism of $\mathrm{NaCl}$ and the tolerance of birds to various concentrations of $\mathrm{NaCl}$ or sea water (for example, see Bartholomew \& Cade, 1963; Cade, 1964; Dawson et al., 1965; MacMillen \& Trost, 1966; Harriman, 1967; Harriman \& Nance, 1968), and the results have been interpreted only in terms of the osmotic effects of $\mathrm{NaCl}$. Since sea water contains appreciable concentrations of $\mathrm{Ca}$ and Mg-10.4 mM Ca, 54.7 mM Mg (Barnes, 1954) - and since saline desertic waters frequently contain considerable amounts of $\mathrm{Ca}$ and $\mathrm{Mg}$ (Margat, 1961; Williams \& Siebert, 1963), it is desirable to know what physiological effects these biologically

* Present address: Division of Science \& Mathematics, McKendree College, Lebanon, Illinois 62254. 
active ions may have on birds. Such knowledge would contribute to a better understanding of the physiological adaptations of birds for utilizing such waters. Therefore, I did some experiments with quail (Coturnix coturnix) to learn something about their abilities to tolerate and excrete $\mathrm{Mg}$ and $\mathrm{Ca}$ in their drinking water, the excretory pathways involved in their salt metabolism, and the possible function of the cloaca and rectum in salt and water balance.

I chose the $120 \mathrm{~g}$ quail for the experiments because it can be kept in good condition in small individual cages that take up relatively little space, and it is big enough to allow sampling of blood and urine in volumes sufficient for analysis of several cations per sample. The quail employed came from a breeding colony maintained in the Department of Zoology, the University of Michigan, and were derived from the Japanese subspecies, C. c. japonica. The species occupies a wide geographic range in Eurasia and Africa.

\section{MATERIALS AND METHODS}

Twenty-eight male quail aged 6-22 months were employed. The mean body weight of these birds during experiments was $119 \cdot 8 \mathrm{~g}$, range $85 \cdot 9-156 \cdot 8 \mathrm{~g}$, s.d. $14 \cdot 1$. The birds were housed in individual wire cages $30.4 \mathrm{~cm}$ (12 in.) to a side, and were maintained on a commercial diet (Purina Game Bird Breeder Layena) which I found to contain 0.230 m-equiv/g $\mathrm{Mg}, 1.05 \mathrm{~m}$-equiv/g Ca, 0.141 m-equiv/g Na, and 0.305 m-equiv/g K.

\section{Acute and chronic loading regimens}

To study the effects of the intake of $\mathrm{CaCl}_{2}$ and $\mathrm{MgCl}_{2}$ on cation metabolism in the quail, I gave solutions of these salts to the birds either over a period of days, referred to as "chronic loading", or in a single dose, termed "acute loading". The regimen for chronic loading consisted of substituting solutions of $\mathrm{MgCl}_{2}$ or $\mathrm{CaCl}_{2}$ (or distilled water in controls) for their usual drinking water for 4 or more days. In some cases individual quail would not drink the higher concentrations of $\mathrm{CaCl}_{2}$ or $\mathrm{MgCl}_{2}$, and so these birds were given regular doses of the solution by stomach tube for at least 3 days prior to the next step. Food and fluid were then removed from the cages for $20-24 \mathrm{hr}$, and at the end of this period of fasting, $3 \mathrm{ml}$ of the solution were injected into the crop or stomach through polyethylene tubing (PE-50/S36, Clay-Adams, Inc., New York) inserted through the esophagus, and the fluids voided by the birds over the subsequent 4 or $5 \mathrm{hr}$ were collected. Acute loading consisted of removing food and water from cages of birds previously maintained on tap water, injecting $3 \mathrm{ml}$ (in a few instances $5 \mathrm{ml}$, see Table 1) of the designated fluid by stomach tube 20-24 hr later, then collecting fluids voided during the subsequent $4-5 \mathrm{hr}$.

\section{Methods of collecting urinary fuids}

Two methods were employed in collecting the fluids voided by the experimental quail. In one series of experiments, the birds were placed in individual wire cages (their usual living quarters) in a darkened room over pans containing light mineral oil about $1 \mathrm{~cm}$ deep so that as the birds voided the fluid spontaneously, it fell into the oil and sank. These fluids were then aspirated from beneath the oil at the end of the collection period in a Pasteur capillary pipette and mixed so that no distinction was made between urinary fluid and any fluid that might have passed unabsorbed through the gut. The fluids thus collected will be referred to as "spontaneously voided urine". Fasting of the quail before beginning the collection of the fluids minimized fecal contamination.

The second method of collecting fluid was designed to obtain urine directly as it passed into the cloaca from the ureters. This would minimize both contamination by unabsorbed fluid from the gut and the effects of cloacal or rectal reabsorption of water or solutes in the 
urine. A collecting device of polyethylene tubing (Clay-Adams, Inc.) and rubber balloons was fashioned (Fig. 1) so that when it was insertcd into the cloaca and rectum of the quail and held in place by stitches between the polyethylene sheet collar and the skin surrounding the cloaca, one tube opened near the ureter on one side of the cloaca, and the other tube extended into the large intestine and opened near the level of the paired ceca. During the insertion of this device, birds were anaesthetized with $0.40 \mathrm{ml}$ of Equi-Thesin (JensenSalisbery Laboratories, Kansas City, Mo.) injected into the pectoral muscles. The quail remained under the effects of the drug for varying periods during the subsequent injection of the salt solution by stomach tube and collection of fluids. The quail then were held in individual cages in a darkened room while the fluids accumulated in the balloons attached to the tubes. This method of fluid collection is subsequently referred to as "intubation".

In an effort to check against contamination of urine by intestinal fluids, the solutions injected into the crops of the intubated quail were colored by dye (Fast Green FCF), which passed unabsorbed through the gut. Rarely was fluid in the urinary collecting bag colored by dye, whereas about one-third of the collections in the intestinal bag had traces of green dye. Urine that was colored by green dye was discarded.

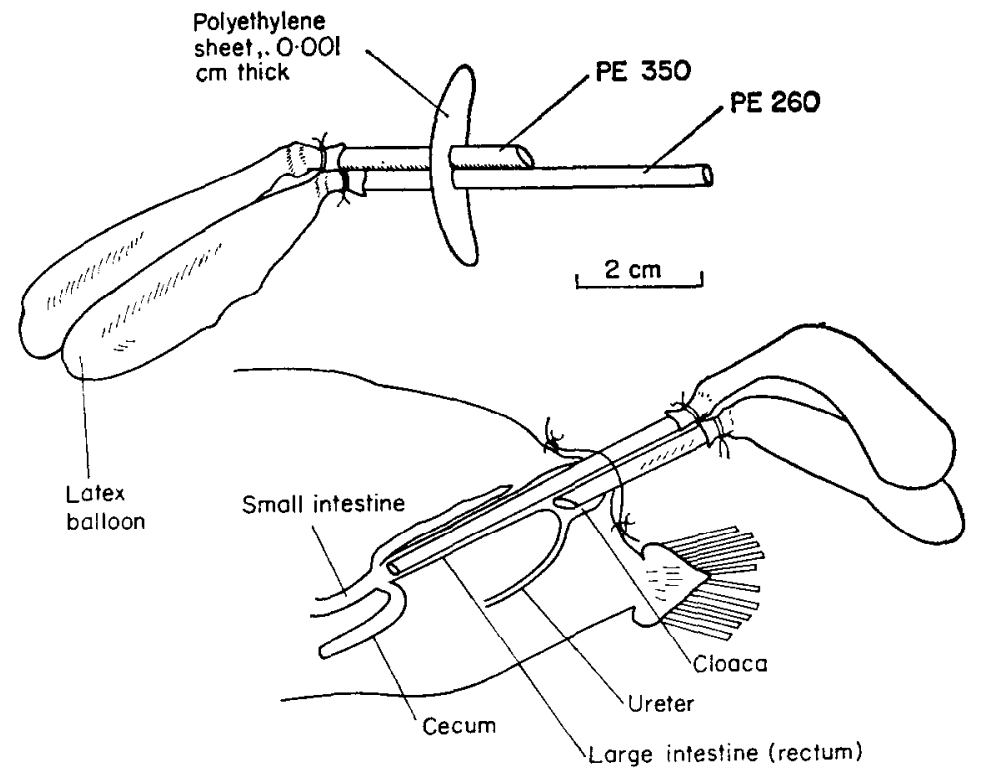

Fig. 1. Diagram of the device employed to collect ureteral urine from the cloaca, and intestinal fluids from the anterior end of the rectum, showing the manner of insertion. The diagram shows the quail on its back, as it was held during insertion of the tubes.

\section{Blood samples}

Blood was obtained from unanaesthetized quail by heart puncture with a 26 ga., 1 in. long hypodermic needle on a $1 \mathrm{~cm}^{3}$ heparinized glass tuberculin syringe. The needle was inserted between the furculum along the dorsal side of the sternum. Sodium-heparin was used as the anticoagulant, and distilled water drawn into heparinized syringes and treated in the same manner as the blood had 1.5-3.0 m-equiv/1. Na. Therefore, the plasma $\mathrm{Na}$ values presented here must be considered to be elevated by 2-3 per cent owing to the presence of 
the heparin. Four-tenths to $0.8 \mathrm{ml}$ of blood was drawn into the syringe, and the syringe was rocked gently to mix the blood with the heparin. The blood was then placed in capillary tubes (Kimax No. 34500, $100 \mathrm{~mm}$ long) which were closed and centrifuged for $20 \mathrm{~min}$ at $3000 \mathrm{rev} / \mathrm{min}$. The hematocrit was determined, the tube broken just above the packed cells, and the plasma sealed in the remainder of the capillary tube and stored in a freezer for subsequent analysis.

\section{Treatment of urinary fluids}

The fluid voided by the birds was centrifuged in $15 \mathrm{ml}$ graduated tubes and the volume of solids (including uric acid and occasional small amounts of fecal material) and of clear fluid estimated. Concentrated nitric acid was then added to the fluid in the proportion of $0.1 \mathrm{ml}$ acid to $1 \mathrm{ml}$ of clear liquid, and the mixture was shaken and allowed to stand at room temperature overnight. The purpose of this acidification was to put into solution $\mathrm{Mg}$ and $\mathrm{Ca}$ that may have been in the form of insoluble carbonates or urates, and to release $\mathrm{Na}$ or $\mathrm{K}$ which might be bound as insoluble urates (the urates thus being converted to the less soluble uric acid with release of the metal ions). The ncxt day the acidificd fluids were centrifuged again and the clear supernate sealed in capillary tubes and frozen for future analysis. In calculating the ion concentrations of the urinary fluids as they came from the quail, all subsequently determined values were multiplied by the appropriate factor owing to the dilution of the fluid with the acid, so that the concentrations given in the results reflect total ions excreted per volume of water, although some of these ions may have initially been in insoluble compounds.

\section{Ion analysis}

Sodium and potassium were determined by flame photometry (Coleman Model 21 Flame Photometer). Magnesium was determined with the dye Clayton Yellow as described by Natelson (1961, in conjunction with a Coleman Junior Spectrophotometer Model 6C.

Calcium was determined by two methods. For plasma, total Ca and $\mathrm{Mg}$ were determined by a modification of the method described by Grette (1953), and the concentration of Ca was taken as the difference between this value and the value for $\mathrm{Mg}$ alone as determincd by the use of Clayton Yellow. For urinary fluids, $\mathrm{Ca}$ was determined by flame photometry using standards that contained the same ranges of $\mathrm{Na}, \mathrm{K}$ and $\mathrm{Mg}$ as the samples. Precision of these methods was within 6 per cent or better.

\section{RESULTS}

\section{Plasma ions and hematocrit}

Table 1 lists plasma values of birds subjected to both chronic and acute loading. Birds given chronic loads of $\mathrm{MgCl}_{2}$ had significantly elevated hematocrits $(P<0.05$, two-tailed $t$-test) compared to the control group given distilled water, whereas none of the other experimental groups had hematocrits significantly different from the controls. Quail receiving chronic loading of $\mathrm{MgCl}_{2}$ showed reduced levels of $\mathrm{Ca}$ in the plasma. In birds receiving $0.084 \mathrm{M} \mathrm{MgCl}_{2}$ this resulted in a level of plasma Ca significantly different from the controls $(P<0.02$, two-tailed $t$-test). Quail receiving loads of $\mathrm{MgC1}_{2}$ showed a tendency to have elevated $\mathrm{Mg}$ concentrations in the plasma (0.099 $\mathrm{M} \mathrm{MgCl}_{2}$ acute, $P<0.05 ; 0.084 \mathrm{M} \mathrm{MgCl}_{2}$ chronic, $\left.P \ll 0.01\right)$. Sodium concentrations in the plasma varied considerably, but showed no significant change relative to experimental regimens. Potassium showed no significant changes in relation to regimen. 
METABOLISM OF SALTS BY QUAIL

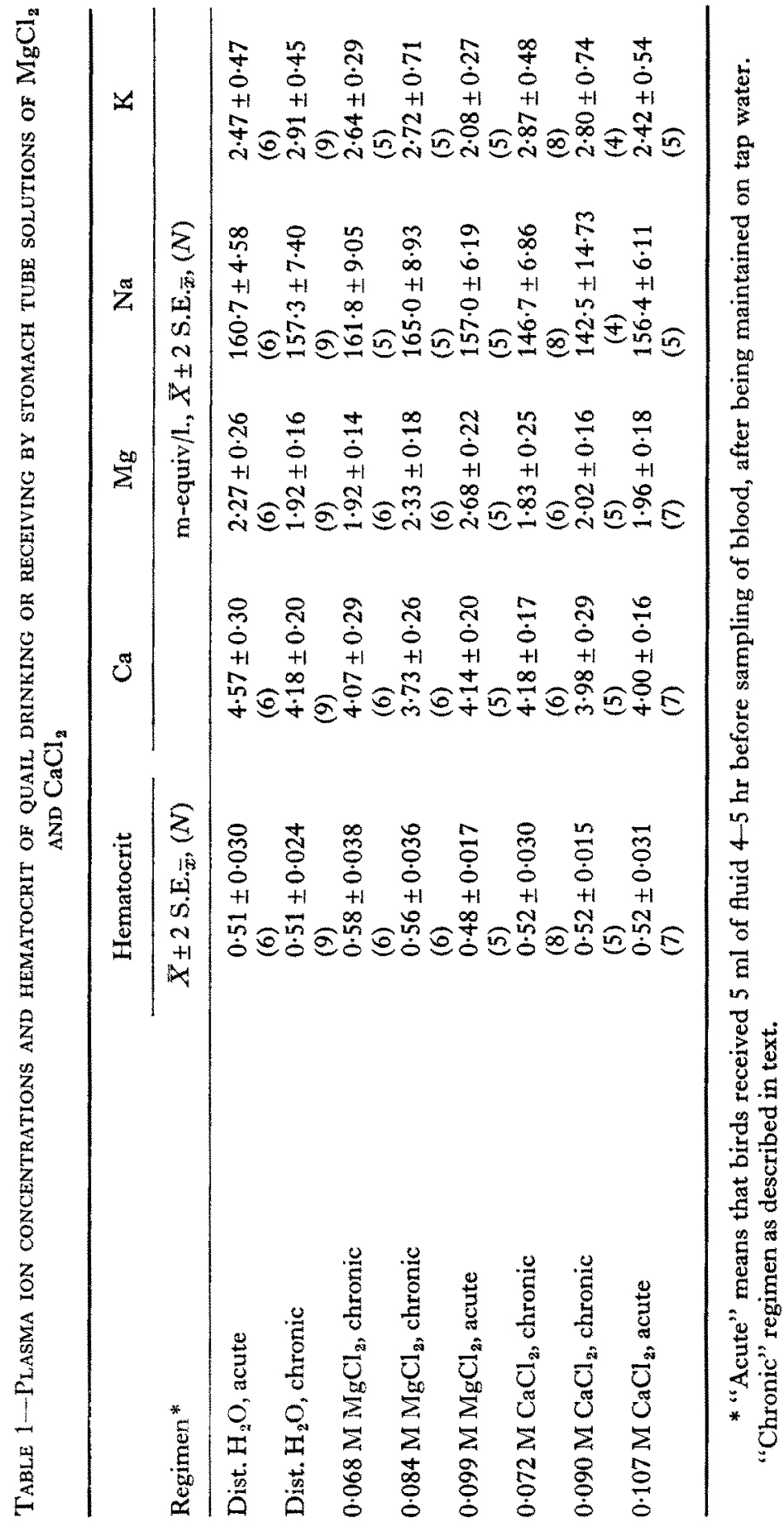




\section{Cations in spontaneously voided urinary fluids}

Table 2 lists ion concentrations in the fluid voided spontaneously by birds subjected to chronic loading regimens. Some individuals receiving $\mathrm{MgCl}_{2}$ voided fluid having concentrations of $\mathrm{Mg}$ in excess of that in the fluids they consumed. The quail receiving $\mathrm{MgCl}_{2}$ solutions produced fluid with very significantly elevated concentrations of $\mathrm{Ca}$, and the converse is true for the quail receiving $\mathrm{CaCl}_{2}$ solutions.

All the quail that received loads of $\mathrm{Ca}$ and $\mathrm{Mg}$ produced excretory fluids with elevated concentrations of $\mathrm{Na}$. There was no significant change in concentrations of $\mathrm{K}$.

\section{Cations in urine collected by intubation of the cloaca}

Table 3 lists ion concentrations in urine taken from the cloaca at the opening of the ureter in quail subjected to acute and chronic loading regimens. Calcium did not vary significantly in relation to regimen, unlike the situation noted in the spontaneously voided fluids. Levels of $\mathrm{Mg}$ were significantly elevated in urine of quail subjected to $\mathrm{Mg}$ loading, but not in that of birds subjected to $\mathrm{Ca}$ loading. With $\mathrm{Mg}$ loading the concentration of $\mathrm{Mg}$ in urine collected by intubation was much lower than in the spontaneously voided fluid (compare with Table 2). Concentrations of $\mathrm{Na}$ did not vary significantly with regimen. Concentrations of $\mathrm{K}$ also appeared not to vary significantly, except possibly in the group receiving chronic loading with $0.072 \mathrm{M} \mathrm{CaCl}_{2}$, where urinary $\mathrm{K}$ was considerably lower than in any of the other groups. However, it is clear that a larger sample size is needed to confirm whether or not this apparent decline is significant.

It is noteworthy that urine from intubated quail invariably had higher concentrations of $\mathrm{K}$ than did spontaneously voided fluids.

\section{Rates of ion excretion}

Table 4 lists average rates of ion excretion during the $4-5 \mathrm{hr}$ period of fluid collection in all experimental groups. The values from intubated quail represent the sum of values from the intestinal and cloacal samples. The intubated quail had significantly elevated rates of water excretion compared to the birds that were voiding spontaneously.

In most instances, rates of ion excretion reflected the changes in concentrations noted above. Thus, birds receiving chronic loads of $\mathrm{Mg}$ and $\mathrm{Ca}$ had significantly elevated rates of excretion of $\mathrm{Na}$. Intubated quail had highly significantly elevated rates of $\mathrm{K}$ loss compared to the other quail, owing both to their increased urinary concentration of $\mathrm{K}$ and their increased rate of fluid production. Loading with $\mathrm{Mg}$ elevated rates of $\mathrm{Ca}$ excretion by birds voiding spontaneously, and the converse was true for birds given $\mathrm{Ca}$ loads. However, intubated quail did not show significant increases in excretion of $\mathrm{Ca}$ when given $\mathrm{Mg}$, and although their rates of $\mathrm{Ca}$ excretion were somewhat elevated when they were given $\mathrm{Ca}$, these rates were far below those for comparable birds that were voiding spontaneously. 
METABOLISM OF SALTS BY QUAIL

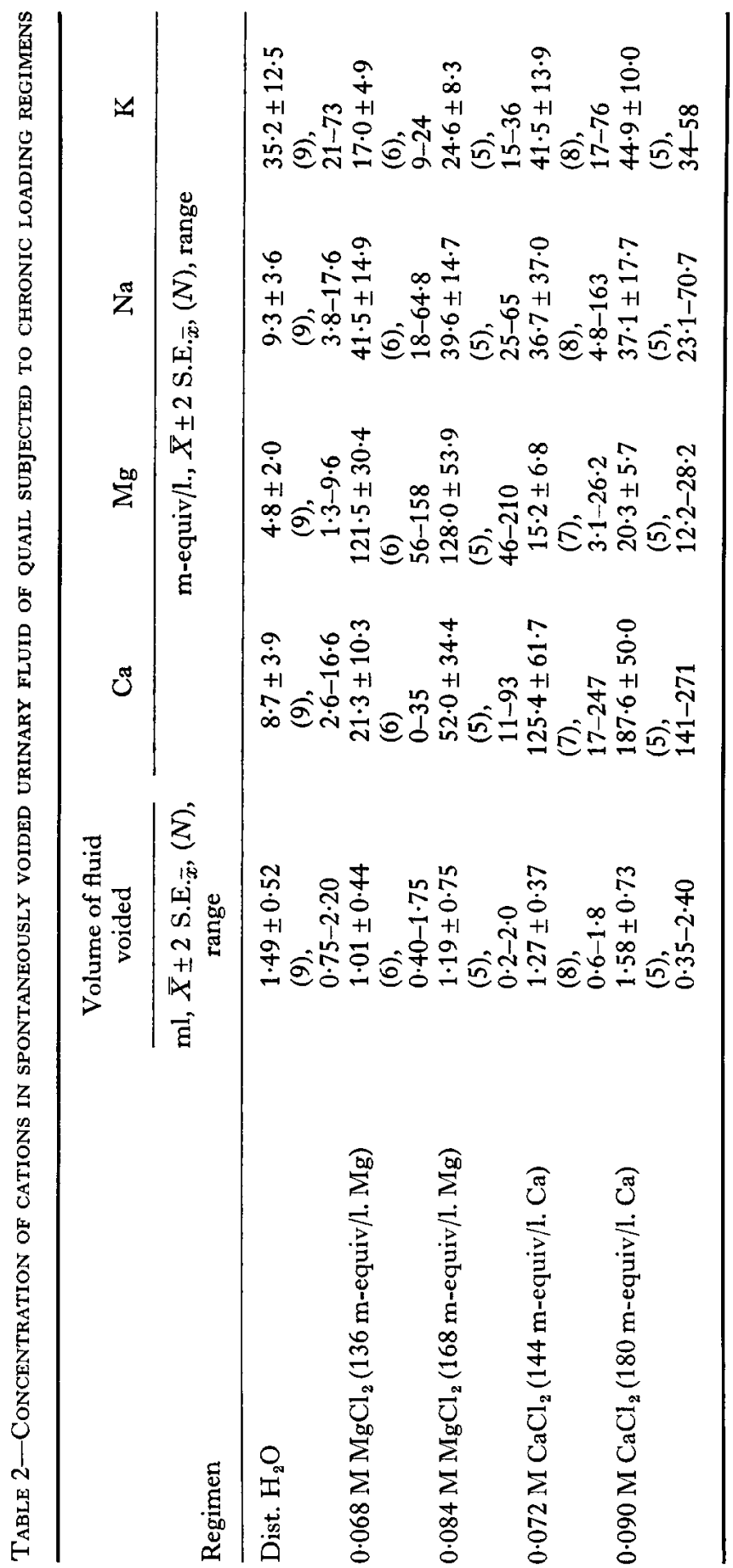


Table 3-Concentration of cations in urine collected from the cloaca at the MOUTH OF A URETER IN QUAIL SUBJECTED TO ACUTE AND CHRONIC LOADING RECIMENS

\begin{tabular}{|c|c|c|c|c|}
\hline \multirow{3}{*}{$\frac{\text { Regimen }}{\text { Dist. } \mathrm{H}_{2} \mathrm{O} \text {, acute }}$} & $\mathrm{Ca}$ & $\mathrm{Mg}$ & $\mathrm{Na}$ & $\mathrm{K}$ \\
\hline & \multicolumn{4}{|c|}{ m-equiv/l., $\bar{X} \pm 2$ S.E $\bar{x},(N)$, range } \\
\hline & $\begin{array}{l}6 \cdot 1 \pm 2 \cdot 9 \\
(14)_{3} \\
1 \cdot 1-18 \cdot 9\end{array}$ & $\begin{array}{l}18 \cdot 9 \pm 5 \cdot 7 \\
(14) \\
6 \cdot 2-37.9\end{array}$ & $\begin{array}{l}14 \cdot 4 \pm 5 \cdot 9 \\
(14) \\
2 \cdot 7-39 \cdot 8\end{array}$ & $\begin{array}{l}91 \cdot 5 \pm 16 \cdot 0 \\
(14) \\
36-144\end{array}$ \\
\hline $\begin{array}{c}0.068 \mathrm{M} \mathrm{MgCl}_{2}, \text { acute }(136 \\
\text { m-cquiv/l. Mg) }\end{array}$ & $\begin{array}{l}4 \cdot 7 \pm 5.9 \\
(8) \\
0 \cdot 2-25 \cdot 0\end{array}$ & $\begin{array}{l}60 \cdot 1 \pm 12 \cdot 9 \\
(8) \\
32 \cdot 4-84 \cdot 2\end{array}$ & $\begin{array}{l}10 \cdot 1 \pm 6 \cdot 1 \\
(8) \\
2 \cdot 7-28 \cdot 6\end{array}$ & $\begin{array}{l}88 \cdot 1 \pm 15 \cdot 2 \\
(8) \\
58-117\end{array}$ \\
\hline $0.068 \mathrm{M} \mathrm{MgCl}_{2}$, chronic & $\begin{array}{l}5 \cdot 9 \pm 9 \cdot 5 \\
(5) \\
0 \cdot 6-24.8\end{array}$ & $\begin{array}{l}46 \cdot 3 \pm 19 \cdot 9 \\
(5) \\
26 \cdot 4-83 \cdot 5\end{array}$ & $\begin{array}{l}18 \cdot 0 \pm 15 \cdot 5 \\
(5) \\
3 \cdot 9-47 \cdot 0\end{array}$ & $\begin{array}{l}125 \cdot 0 \pm 123 \cdot 5 \\
(5) \\
42-371\end{array}$ \\
\hline $\begin{array}{l}0.072 \mathrm{M} \mathrm{CaCl}_{2}, \text { acute }(144 \\
\text { m-equiv/1. Ca) }\end{array}$ & $\begin{array}{l}8 \cdot 9 \pm 5 \cdot 3 \\
(8) \\
0 \cdot 9-22.9\end{array}$ & $\begin{array}{l}24 \cdot 5 \pm 2 \cdot 7 \\
(8) \\
19 \cdot 9-29 \cdot 6\end{array}$ & $\begin{array}{l}12 \cdot 4 \pm 5 \cdot 7 \\
(8) \\
2 \cdot 7-26 \cdot 9\end{array}$ & $\begin{array}{l}82 \cdot 0 \pm 16 \cdot 7 \\
(8) \\
46-117\end{array}$ \\
\hline $0.072 \mathrm{M} \mathrm{CaCl}_{2}$, chronic & $\begin{array}{l}3 \cdot 4 \pm 1 \cdot 5 \\
(5) \\
0 \cdot 9-5 \cdot 0\end{array}$ & $\begin{array}{l}17 \cdot 1 \pm 3 \cdot 9 \\
(5) \\
12 \cdot 1-23 \cdot 3\end{array}$ & $\begin{array}{l}9 \cdot 0 \pm 3 \cdot 8 \\
(5) \\
4 \cdot 4-14 \cdot 3\end{array}$ & $\begin{array}{l}49 \cdot 2 \pm 15 \cdot 7 \\
(5) \\
29-67\end{array}$ \\
\hline
\end{tabular}

Intubated quail received additional $\mathrm{Mg}$ when they were anaesthetized $(0.4 \mathrm{ml}$ of Equi-Thesin contains $0.14 \mathrm{~m}$-equiv. $\mathrm{Mg}$ ), which may account for the elevated rate of excretion of $\mathrm{Mg}$ in the intubated controls receiving distilled water as compared to controls voiding spontaneously.

\section{DISCUSSION}

\section{Plasma ions and hematocrit}

The elevation of the hematocrit of quail subjected to chronic Mg loading may indicate a loss of water from the plasma. It is not known whether this apparent water loss is the result of a shift of water and electrolytes to a different fluid compartment, or whether it represents a dehydration of the organism. The regimens of $\mathrm{CaCl}_{2}$ did not have this effect, although the $\mathrm{CaCl}_{2}$ solutions given to the quail had the same osmosity as did the $\mathrm{MgCl}_{2}$ solutions; so the difference cannot result from differences in osmotic concentration of the solutions. If dehydration did occur, it may be the result of reduced absorption of water in the gut owing to a purgative action by $\mathrm{MgCl}_{2}$. Cunningham (1933) noted that high levels of $\mathrm{Mg}$ in the food of rats gave them diarrhea.

The reduced concentration of $\mathrm{Ca}$ in plasma of quail subjected to chronic $\mathrm{Mg}$ loading indicates a slight loss of $\mathrm{Ca}$ from the plasma. It is intriguing that the sum of plasma $\mathrm{Mg}$ and plasma $\mathrm{Ca}$ in all chronically loaded birds remained quite constant-near $6.0 \mathrm{~m}$-equiv/1.-regardless of concentration of $\mathrm{MgCl}_{2}$, which suggests a reciprocal relationship between levels of $\mathrm{Ca}$ and $\mathrm{Mg}$ in plasma of birds subjected to chronic $\mathrm{Mg}$ loading. Similar relationships have been observed in 


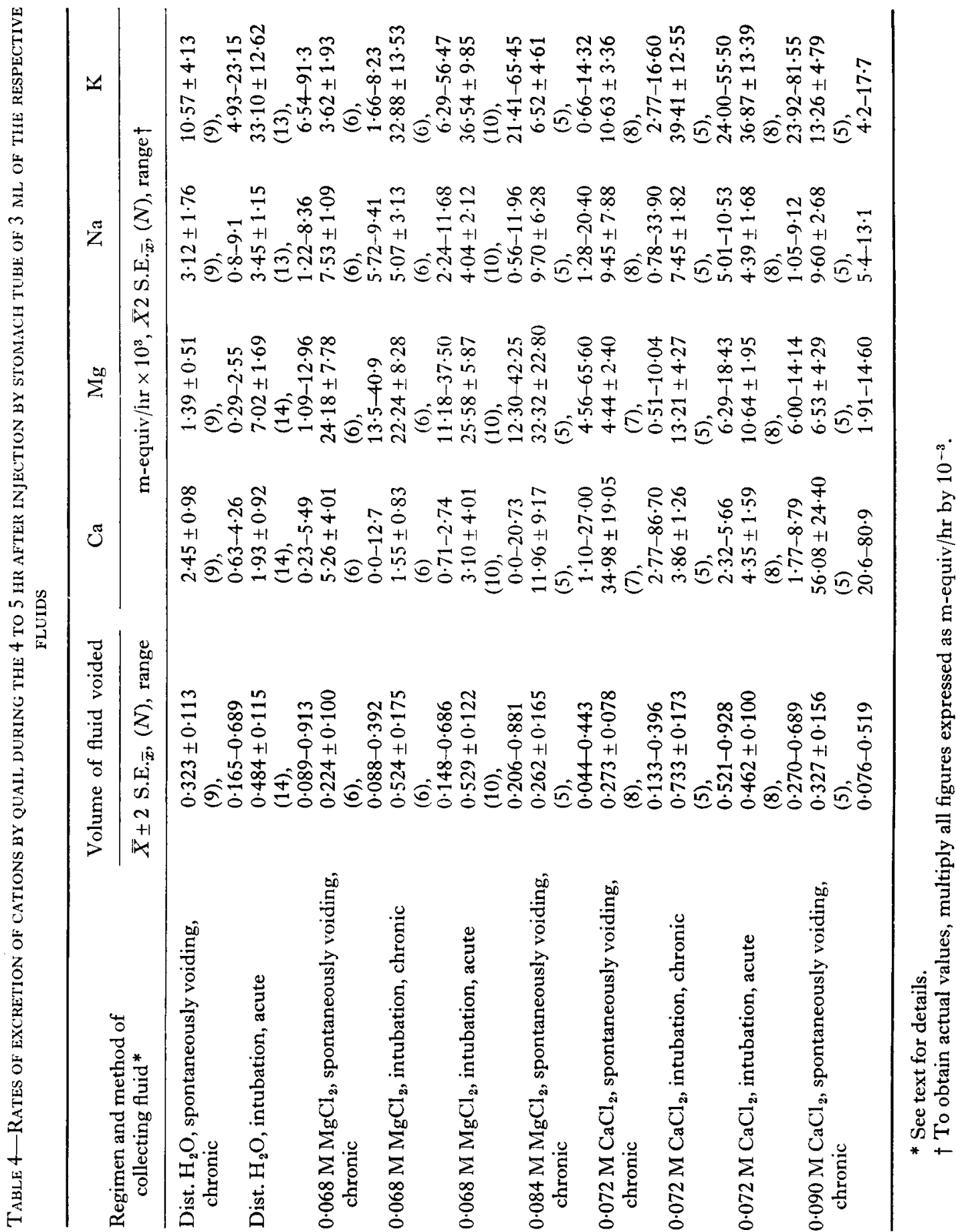


laboratory rats. Cunningham (1933) observed that rats fed diets containing supplementary $\mathrm{Mg}$ had elevated serum $\mathrm{Mg}$ and slightly lowered serum $\mathrm{Ca}$. Alcock \& MacIntyre (1962) observed that rats fed a diet deficient in $\mathrm{Mg}$ had increased plasma $\mathrm{Ca}$ and decreased plasma $\mathrm{Mg}$; and Clark (1968) observed a slight lowering of serum $\mathrm{Ca}$ in rats that were given solutions of $\mathrm{MgCl}_{2}$ to drink.

\section{Cations in urinary fluid}

The increased rates of excretion of $\mathrm{Ca}$ and $\mathrm{Mg}$ by quail receiving loads of $\mathrm{Mg}$ and $\mathrm{Ca}$, respectively, agree with observations on mammals. Thus Malcolm (1905) observed that when dogs were given additional $\mathrm{MgCl}_{2}$ in their food, there was an increase in urinary output of $\mathrm{Ca}$, although additional $\mathrm{CaCl}_{2}$ in the food did not appear to elevate urinary $\mathrm{Mg}$. Mendel \& Benedict (1909a) injected $\mathrm{MgSO}_{4}$ or $\mathrm{MgCl}_{2}$ subcutaneously or intraperitoneally into dogs, cats and rabbits, and observed increases in urinary output of both $\mathrm{Ca}$ and $\mathrm{Mg}$. When they injected $\mathrm{CaCl}_{2}$ intravenously into rabbits and dogs, Mendel \& Benedict (1909b) observed increases in urinary $\mathrm{Ca}$ and $\mathrm{Mg}$. More recently, Samiy et al. (1960) found that when dogs received infusions of $\mathrm{MgCl}_{2}$, the excretion of $\mathrm{Ca}$ was markedly increased, and when they were infused with $\mathrm{CaCl}_{2}$ the excretion of $\mathrm{Mg}$ was slightly incrcased. Clark (1968) found that rats drinking solutions of $\mathrm{MgCl}_{2}$ had significantly increased urinary $\mathrm{Ca}$, while Alcock \& MacIntyre (1962) observed that rats eating a diet deficient in $\mathrm{Mg}$ had decreased urinary excretion of $\mathrm{Mg}$ and $\mathrm{Ca}$.

Explanations of this interaction of $\mathrm{Mg}$ and $\mathrm{Ca}$ have varied with experimental treatment. Results of studies involving dietary supplements of $\mathrm{Mg}$ and $\mathrm{Ca}$ tend to indicate that the presence of $\mathrm{Mg}$ in the gut enhances absorption of $\mathrm{Ca}$ (Clark, 1968). On the other hand, studies of absorption and excretion of $\mathrm{Ca}$ and $\mathrm{Mg}$ by rats fed diets deficient in one or the other of these elements have been interpreted to indicate that the deficiency of one of the ions enhances intestinal absorption of the other (Alcock \& MacIntyre, 1962). Therefore, it appears unlikely that the effect is owing only to the activity of a common transport mechanism in the intestine. Studies of the action of the parathyroid gland on levels of plasma $\mathrm{Ca}$ in laboratory rats injected with $\mathrm{MgCl}_{2}$ indicate that hypermagnesemia inhibits parathyroid activity (Gitelman et al., 1968), suggesting that the parathyroids may mediate the interaction between $\mathrm{Ca}$ and $\mathrm{Mg}$. Studies of the renal excretion of $\mathrm{Mg}$ and $\mathrm{Ca}$ of dogs infused with $\mathrm{MgCl}_{2}$ and $\mathrm{CaCl}_{2}$ suggest also that $\mathrm{Mg}$ and $\mathrm{Ca}$ compete for a common renal tubular reabsorptive mechanism (Samiy et al., 1960). In any case, it appears that the regulatory systems involved are not capable of clearly differentiating the two divalent cations in these mammals and in the quail.

While my observations on excretion of $\mathrm{Ca}$ and $\mathrm{Mg}$ in quail are consistent with findings for various mammals, and may reflect activities of homologous regulatory systems, it should be noted that the avian urinary tract empties into the cloaca where the urine may be modified by mixing with intestinal fluids and feces, or by reabsorptive and secretory activities of the cloaca or large intestine. Urine characteristically moves into the large intestine right up to the ceca after it enters the 
cloaca from the ureters (Skadhauge \& Schmidt-Nielsen, 1965; Skadhauge, 1967, 1968; Nechay et al., 1968). Therefore, I performed the experiments with the intubated quail in an attempt to see what effect the cloaca and intestine may have on excretion of cations and water. Taken at face value my results indicate that about half of the water in the urine is reabsorbed in the cloaca or rectum. This is consistent with observations by Skadhauge (1968) on roosters that had been deprived of water for $36 \mathrm{hr}$. My results also show that the $\mathrm{Ca}$ in ureteral urine did not reflect the $\mathrm{Ca}$ loads administered. Much of the $\mathrm{Ca}$ therefore may pass through the gut without being absorbed, or it may be secreted back into the intestinal or cloacal lumen after being absorbed. I believe it is most likely that not all of the $\mathrm{Ca}$ was being absorbed in the gut, but was precipitated as carbonate in the intestine and then mixed with the urine in the rectum and cloaca before the urine was voided. It appears, though, that the $\mathrm{Mg}$ was absorbed in the intestine, and excreted through the kidney. This difference between absorption of $\mathrm{Ca}$ and of $\mathrm{Mg}$ in the intestine would account for the greater effect of $\mathrm{Mg}$ on the birds' systems and the consequent enhancement of $\mathrm{Ca}$ excretion by birds receiving loads of $\mathrm{Mg}$.

There is a possibility that the additional handling of the quail attendant to the insertion of the collecting device may have induced diuresis (Hester et al., 1940), which could partly account for the higher rates of water loss in intubated birds. The anaesthetic contained $177 \mathrm{mM} / 1 . \mathrm{MgSO}_{4}$, and the additional $\mathrm{Mg}$ thus administered may account for increased excretion of $\mathrm{Mg}$ in intubated birds compared to their spontaneously voiding counterparts. The anaesthesia and intubation may have been factors that contributed to the three to sixfold higher rates of $\mathrm{K}$ excretion by these birds than in normal birds, although the possibility that $\mathrm{K}$ is normally reabsorbed in the rectum or cloaca cannot be eliminated. In this regard it is well to cite the in vivo perfusion studies on chicken cloaca by Skadhauge (1967) which demonstrated a net secretion of $\mathrm{K}$ into the lumen of the coprodeum and large intestine when the concentration of $\mathrm{K}$ in the perfusate was less than 90 $\mathrm{m}$-equiv/l. It also appears relevant that the rate of excretion of $\mathrm{K}$ by roosters which had been deprived of water for about $36 \mathrm{hr}$ did not differ significantly between birds voiding urine spontaneously and birds in which urine was collected through polyethylene funnels sewn over the ureteral openings (Skadhauge, 1968). Thus it appears that quail and chicken might differ in regard to the roles of the kidneys and of the cloaca and rectum in the excretion of $K$.

The increased excretion of $\mathrm{Na}$ by quail receiving loads of $\mathrm{Ca}$ and $\mathrm{Mg}$ is intriguing. The quail voiding urine spontaneously had concentrations of $\mathrm{Na}$ increased 4- to 5-fold when given $\mathrm{MgCl}_{2}$ or $\mathrm{CaCl}_{2}$, and their total rates of excretion of $\mathrm{Na}$ were 2 to 3 times higher than controls given distilled water. However, intubated birds did not show such clear-cut increases in rates of $\mathrm{Na}$ excretion when given $\mathrm{Ca}$ and $\mathrm{Mg}$, and the concentration of $\mathrm{Na}$ in the ureteral urine of these birds did not vary significantly. This seems to indicate that $\mathrm{Na}$ was secreted into the cloaca or rectum of quail subjected to $\mathrm{Mg}$ and $\mathrm{Ca}$ loading, rather than excreted through the kidneys. 
Spontaneously voided urine of ducks (Anas platyrhinchos) maintained on hypertonic saline had significantly higher concentrations of $\mathrm{Ca}$ than that of ducks maintained on tap water (Holmes et al., 1968). It is also interesting in this connection that the clearances of $\mathrm{Na}$ and unbound $\mathrm{Ca}$ by dogs are linearly related under varying conditions of diuresis, salt loading, and glomerular filtration rate (Walser, 1961; Massry et al., 1967). It is tempting to hypothesize that the simultaneous increases in urinary $\mathrm{Na}$ and $\mathrm{Ca}$ in the quail and duck are manifestations of the same physiological process. At any rate, it appears that the interactions between $\mathrm{K}, \mathrm{Na}, \mathrm{Ca}$ and $\mathrm{Mg}$ in the processes of avian salt metabolism are rather complicated; and investigators of utilization of sea water by birds should consider the complex physiological interactions of the various ions when interpreting their results.

Further studies are needed to define precisely the roles of intestinal absorption, renal excretion, and cloacal or rectal reabsorption and secretion (and nasal salt excretion in birds having functional nasal glands) in avian salt metabolism.

\section{SUMMARY}

To investigate how waters, such as saline desertic waters, that contain $\mathrm{Mg}$ or $\mathrm{Ca}$ as well as Na may affect the salt and water metabolism of birds that drink them, solutions of $\mathrm{CaCl}_{2}$ and $\mathrm{MgCl}_{2}$ were administered to quail (Coturnix coturnix) perenterally and then concentrations of cations in their plasma and urine were measured. Two methods of administering $\mathrm{Ca}$ and $\mathrm{Mg}$ to the quail were employed, namely (i) "acute loading" whereby quail were maintained on tap water, held 20-24 hr without food or water, then given 3-5 ml of $\mathrm{MgCl}_{2}$ or $\mathrm{CaCl}_{2}$ solution by stomach tube; and (ii) "chronic loading" whereby the quail were maintained on the designated salt solution for at least 4 days, and then were fasted and injected with the solution. Urinary fluids were collected during the 4-5 hr after injection of the salt solution by stomach tube, either as spontaneously voided urine, or by means of polyethylene tubes inserted into the cloaca and the rectum so as to collect ureteral urine that was not modified by contact with rectal fluids and mucosa.

Quail receiving chronic loading with $0.084 \mathrm{M} \mathrm{MgCl}_{2}$ had significantly reduced plasma Ca; and these quail as well as those given acute loads of $0.099 \mathrm{M} \mathrm{MgCl}_{2}$ had significantly elevated plasma Mg (plasma sampled 4-5 hr after injection of $\mathrm{MgCl}_{2}$ by stomach tube).

The spontaneously voiding quail given loads of $\mathrm{MgCl}_{2}$ had urine with significantly elevated concentrations of $\mathrm{Ca}$, and the converse was true for quail given loads of $\mathrm{CaCl}_{2}$. They also had elevated urinary concentrations of $\mathrm{Na}$ when given $\mathrm{MgCl}_{2}$ or $\mathrm{CaCl}_{2}$, but concentrations of $\mathrm{K}$ were not affected.

Intubated quail produced urine with increased concentrations of $\mathrm{Mg}$ when they received $\mathrm{MgCl}_{2}$; but urinary concentrations of $\mathrm{Ca}$ and $\mathrm{Na}$ were not affected by $\mathrm{Ca}$ and $\mathrm{Mg}$ loading. The concentration of $\mathrm{K}$ in this urine was invariably higher than in spontaneously voided urine. Rates of fluid excretion of intubated quail were about twice as high as of spontaneously voiding quail. 
The results indicate that (i) the regulatory system that deals with divalent cations in the quail is affected similarly by both $\mathrm{Ca}$ and $\mathrm{Mg}$, and does not distinguish completely between the divalent cations; (ii) calcium appears to be less readily absorbed in the gut than is $\mathrm{Mg}$; (iii) excretion of $\mathrm{Na}$ is increased by the intake of $\mathrm{CaCl}_{2}$ or $\mathrm{MgCl}_{2}$; (iv) water appears to be reabsorbed from ureteral urine in the cloaca or rectum; ( $v$ ) excretion of $\mathrm{K}$ was unaffected by increased intake of $\mathrm{CaCl}_{2}$ or $\mathrm{MgCl}_{2}$; (vi) the effects of $\mathrm{CaCl}_{2}$ and $\mathrm{MgCl}_{2}$ on salt metabolism of quail are complex.

Acknowledgements-The experiments were performed while I received a National Institutes of Health post-doctoral training stipend administered through the Department of Zoology, the University of Michigan. Equipment and supplies were provided through the NIH training grant. I thank Dr. William R. Dawson for guidance and support throughout the study, and for his helpful criticisms of the manuscript.

\section{REFERENCES}

ALCOCK N. \& MACINTYRE I. (1962) Inter-relation of calcium and magnesium absorption. Clin. Sci. 22, 185-193.

BarNes H. (1954) Some tables for the ionic composition of sea water. F. exp. Biol. 31, 582588.

Bartholomew G. A. \& Cade T. J. (1963) The water economy of land birds. Auk 80, 504 539.

CADE T. J. (1964) Water and salt balance in granivorous birds. In Thirst-Proceedings of the 1st International Symposizm on Thirst in the Regulation of Body Water, pp. 237-256. Pergamon Press, Oxford.

ClaRK I. (1968) Effects of magnesium ions on calcium and phosphorus metabolism. Am. $\mathcal{F}$. Physiol. 214, 348-356.

Cunningham I. J. (1933) Magnesium in animal diets. The influence of the level of dietary magnesium on the magnesium and calcium contents of the bones, the bodies, and the blood serum of rats. New Zealand Y. Sci. Technol. 15, 191-198.

DAwson W. R. \& BARTholomew G. A. (1968) Temperature regulation and water economy of desert birds. In Desert Biology, Vol. 1 (Edited by Brown G. W., Jr.), pp. 357-394. Academic Press, New York.

Dawson W. R., Shoemaker V. H., Tordoff H. B. \& Borut A. (1965) Observations on the metabolism of sodium chloride in the red crossbill. $A u k$ 82, 606-623.

Grtelman H. J., KukoLJ S. \& Wret L. G. (1968) Inhibition of parathyroid gland activity by hypermagnesemia. Am. F. Physiol. 215, 483-485.

GRETTE K. (1953) Micromethod for the determination of calcium and magnesium in serum. Titration with ethylene-diamine-tetracetate. Scand. F. clin. lab. Invest. 5, 151-154.

Harriman A. (1967) Laughing gulls offered saline in preference and survival tests. Physiol. Zool. 40, 273279.

HaRriman A. E. \& NANCE D. M. (1968) Effects of drinking salt water on $\mathrm{NaCl}$ tolerance and preference in Japanese quail. Am. midl. Nat. 80, 28-33.

Hester H. R., Essex H. E. \& ManN F. C. (1940) Secretion of urine in the chicken (Gallus domesticus). Am. $尹$. Physiol. 128, 592-602.

Holmes W. N., Fletcher G. L. \& Strwart D. J. (1968) The patterns of renal electrolyte excretion in the duck (Anas platyrhynchos) maintained on freshwater and on hypertonic saline. F. exp. Biol. 48, 487-508.

MacMillen R. E. \& Trost C. M. (1966) Water economy and salt balance in white-winged and inca doves. $A u k 83,441-456$. 
Matcolm J. (1905) On the inter-relationship of calcium and magnesium excretion. $\mathcal{F}$. Physiol. 32, 181-190.

Margat J. (1961) Les eaux salées au Maroc. In UNESCO, Salinity Problems in the Arid Zones, Proceedings of the Teheran Symposium, pp. 91-104.

Massry S. G., Coburn J. W., Chapman L. W. \& Kleseman C. R. (1967) Effect of $\mathrm{NaCl}$ infusion on urinary $\mathrm{Ca}^{++}$and $\mathrm{Mg}^{++}$during reduction in their filtered loads, $A m . \mathcal{Y}$. Physiol. 213, 1218-1224.

MENDEL L. B. \& BENEDICT S. R. (1909a) The paths of excretion for inorganic compoundsIV. The excretion of magnesium. Am. F. Physiol. 25, 1-22.

MENDEL L. B. \& BENEDICT S. R. (1909b) The paths of excretion for inorganic compoundsV. The excretion of calcium. Am. F. Physiol. 25, 23-33.

Natelson S. (1961) Microtechniques of Clinical Chemistry, 2nd edn, pp. 292-293. Thomas, Springfield, Ill.

Nechay B. R., Boyarsky S. \& Catacutan-Labay P. (1968) Rapid migration of urine into intestine of chickens. Comp. Biochem. Physiol. 26, 369-370.

Samiy A. H. E., Brown J. L. \& Globus D. L. (1960) Effects of magnesium and calcium loading on renal excretion of electrolytes in dogs. Am.F. Physiol. 198, 595-598.

SKADHAUGE E. (1967) In vivo perfusion studies of the cloacal water and electrolyte resorption in the fowl (Gallus domesticus). Comp. Biochem. Physiol. 23, 483-501.

Skadhauge E. (1968) The cloacal storage of urine in the rooster. Comp. Biochem. Physiol. $24,7-18$.

Skadhauge E. \& Schmidt-Nielsen B. (1965) Cloacal storage and modification of urine in the fowl. Fedn. Proc. 24, 643.

WALSER M. (1961) Calcium clearance as a function of sodium clearance in the dog. Am. $\mathcal{F}$. Physiol. 200, 1099-1104.

Williams W. D. \& SieBerT B. D. (1963) The chemical composition of some surface waters in central Australia. Aust. F. mar. freshw. Res. 14, 166-175.

Key Word Index-Salt metabolism; ion regulation; cations; Japanese quail; quail; Coturnix; urine; renal function; reabsorption; blood plasma; drinking; calcium; magnesium; sodium; potassium. 